\title{
Determination and Comparison of In Vitro Radical Scavenging Activity of Both Garlic Oil and Aqueous Garlic Extracts and Their In Vivo Antioxidant Effect on Schistosomiasis Disease in Mice
}

\author{
Somayyeh Sadrefozalayi ${ }^{1}$, Behnaz Aslanipour², Murat Alan³, Mehmet Calan ${ }^{4 *}$ \\ ${ }^{1}$ Department of Biology, Faculty of science, Urmia University, Urmia, I.R. Iran \\ ${ }^{2}$ Department of Bioengineering, Faculty of Engineering, Ege University, 35100 Bornava, Izmir, Turkey \\ ${ }^{3}$ Department of Obstetrics and Gynecology, Izmir Tepecik Training and Research Hospital, 35120 Tepecik, Izmir, Turkey \\ ${ }^{4}$ Department of Internal Medicine, Izmir Bozyaka Training and Research 14 Hospital, 35170 Bozyaka, Izmir, Turkey.
}

\begin{tabular}{ll}
\hline A R T I C L E I N F O & A \\
Research Article & \\
Received 10 October 2017 & \\
Accepted 26 February 2018
\end{tabular}

Keywords:

Garlic extracts

Antioxidant

Radical scavenging activity

Schistosomiasis

Worms

*Corresponding Author:

E-mail: mehmetdrd@yahoo.com

\begin{abstract}
A B S T R A C T
Garlic has long been utilizing as a folk remedy for various diseases. In this study, the effect of aqueous garlic extract (AGE) $\left(125 \mathrm{mg} \mathrm{kg}^{-1}\right)$, garlic oil extract (GOE) (125 mg $\mathrm{kg}^{-1}$ ), and the combination of both extracts (AGE+GOE) (62.5 from each) was studied over a parasitic disease namely schistosomiasis. Determination of some radical scavenging activities including Ferric Reducing Ability Power, Hydrogen peroxide, DPPH and nitric oxide radical scavenging activities were studied. The antioxidant properties of the mentioned extracts on both normal and Schistosoma mansoni-infected mice was also studied. The liver tissues were analyzed for the level of Malondialdehyde (MDA) and glutathione (GSH) known as biomarkers for oxidative and reducing status, respectively. The results showed that almost all tested extracts showed high effect of radical scavenging activity. Furthermore, remarkable decrease in worms and tissue eggs were analyzed in all tested extracts as AGE + GOE $(1015 \pm 1.41)$ represented higher level of prohibition in total number of worms and eggs compared to infected untreated mice $(1502 \pm 2.13)$. The garlic extracts were potent antioxidants with slight differences.
\end{abstract}

DOI: https://doi.org/10.24925/turjaf.v6i7.820-827.1647

\section{Introduction}

Garlic (Allium sativum L.), one of the first cultivated crops, is commonly used for several purposes due to its therapeutic and medicinal properties both in traditional and modern medicine (FAO, 2013). Garlic has been consumed either as raw vegetable (fresh leaves or dried cloves), or processed in the form of oil, extract and even powder. It has some activities such as antidiabetic, anticancer, immunomodulator, analgesic, antimicrobial, anti-inflammatory, spasmolytic, renal protective, gastroprotective and antioxidant properties for a long time (Lanzotti et al., 2014). Garlic has been introduced as a potent vegetable containing remarkable antioxidant properties due to having two main classes of antioxidant components, called flavonoids and sulfur-containing compounds, such as diallyl sulfide and trisulfide, and allyl-cysteine (Kahkonen et al., 1999; Sattler and Griffin 2003). It has been reported that, Garlic has potential of anti-bacterial and anti-fungal activities and proved to play a significant role in over 100 diseases such as cancer, atherosclerosis and arthritis (Thomas, 1995; Benkeblia, 2005). Garlic supplements are classified into four different groups including commercially available in form of oil capsules, capsule and tablets, soft gel capsule and concentrated extract in powdered form (Bayan et al., 2014). Row garlic along with its oil extracts and powder extracts have shown numerous activities such as reduction of cholesterol and triglycerides of blood levels during the high fat meals intake in human studies (Bayan et al., 2014). Additionally, the most famous brand of garlic extract namely KYOLIC is obtained by keeping maintained at room temperature in the form of sliced and soaked into a water/ethanol mixture for more than 20 months (Amagase and Milner, 1993). Aged garlic extract (AGE), a commercial garlic product, which is manufactured soaking sliced fresh garlic in aqueous ethanol and maturing the extract for up to 10 or 20 months at room temperature was tested and various biological activities (Amagase and Milner, 1993; Kasuga et al., 2001; Morihara et al., 2011) including cardio protective (Rahman and Lowe, 2006), cancer-preventing (Tanaka et al., 2006) and scavenging free radicals (Morihara et al., 2011) have been reported. In another study according to the antioxidant activity of garlic essential oil (Allium sativum) grown in north Indian 
plains, IC50 values for DPPH and nitric oxide scavenging assays were observed as $0.5 \mathrm{mg} / \mathrm{mL}$ and $50 \mu \mathrm{g} / \mathrm{mL}$ respectively (Lawrence and Lawrence, 2011). In another study, antioxidant properties of raw garlic (Allium sativum) extract was investigated and the results showed that raw garlic could be a source of antioxidant based on the results of the DPPH scavenging analysis (Rahman et al., 2012). Some in vivo studies referring to effects of garlic over different diseases have been recorded. Anthony et al., (2005) reported that garlic has displayed potentially new treatments for a range of parasitic infections. It was investigated that the antioxidant and anti-schistosomal effects of AGE alone and in the combination with Nigella sativa (NSO) on normal and Schsitosoma mansoni-infected mice and they represented that AGE was a promising agent in treatment of schistosomiasis disease (EL-Shenawy et al., 2008). Garlic has been used on Asian fish farms for a long time and it has been introduced as a useful anti-parasitic stimulant (Rodgers and Furones, 2009; Jegede, 2012; Schelkle et al., 2013). Garlic has been recorded to have an effect against monogenean parasites reducing Anacanthorus penilabiatus infections in cultivated pacu (Piaractus mesopotamicus) (Martins et al., 2002) Neobenedenia sp. in barramundi (Militz, 2013) and gyrodactylosis in Oreochromis niloticus fry (Abd El-Galil and Aboelhadid, 2012). In another study, immunomodulatory effect of GOE on Schistosoma mansoni infected mice was tested and the results displayed that the critical larval stage of the parasite ( $7 \mathrm{~d}$ post infection) and after $42 \mathrm{~d}$ PI was due to its action on the parasite viability, mobility and fecundity associated with an enhanced immune response of the host towards the parasites (Kamel and ElShinnawy, 2015). The purpose of this study was to investigate in vitro scavenging activity of two garlic extracts including GOE and AGE extracts on some free radicals including determination of DPPH radical scavenging activity, hydrogen peroxide radical scavenging activity $\left(\mathrm{H}_{2} \mathrm{O}_{2}\right)$, superoxide radical scavenging activity, ferric Reducing Ability Power (FRAP) and nitric oxide radical inhibition assay. Besides, the antioxidant effect of mentioned garlic extracts as alternative treatments against schistosomiasis disease was tested in mice determining some hematological parameters such as White blood cells (WBCs), Red blood cells (RBCs), Hemoglobin percentage $(\mathrm{Hb} \%)$, hematocrit value (PCV) and Thrombocytes to analyze the existence of anemia, besides, tissue malondialdehyde (MDA) and glutathione (GSH) were also measured to figure out the tissue damage, the mentioned tested were done to introduce the most effective extract for containing antioxidant effect.

\section{Materials and Methods}

\section{Preparation of Garlic Extracts}

To obtain aqueous extract, peeled garlic (40 g), crushed with distilled water in a mortar, was carefully decanted by pressing and $60 \mathrm{~mL}$ of aqueous extract was extracted. As one milliliter of aqueous extract contained $660 \mathrm{mg}$ of garlic Materials (Sener et al., 2006). To obtain GOE, distillation method was used according to method described by Kamel and El-Shinnawy, (2015).

\section{In vivo Experimental Design}

Forty male Swiss albino mice with weights between 21-23 g were obtained from experimental research center of Urmia University. They were put in polypropylene cages at $25 \pm 2^{\circ} \mathrm{C}$ with $12 \mathrm{~h} / 12 \mathrm{~h}$ light/dark cycle, and had free access to pelletal food with tap water ad libitum. The above-mentioned animals were spontaneously divided into eight groups including five in each, according to the experimental design, which is shown in Table 1. Four groups of mice were infected by exposing them to 50 Schistosoma mansoni (S. mansoni) cercariae with Iranian Strain. The animals were treated by intraperitoneal route (i.p.) with different regime (Table 1) for 28 days (three times per week) starting from $1^{\text {st }}$ day post infection (pi).

Table 1 The experimental design

\begin{tabular}{|c|c|}
\hline $\begin{array}{l}\text { Groups of } \\
\text { mice }\end{array}$ & Treatment Regime \\
\hline $\begin{array}{l}\text { Non- } \\
\text { infected } \\
\text { control }\end{array}$ & $\begin{array}{l}\text { Group I received } 0.1 \mathrm{~mL} \text { of saline } \\
\text { Group II received } 125 \mathrm{mg} \mathrm{kg}-1 \text { of AGE } \\
\text { Group III received } 125 \mathrm{mg} \mathrm{kg}-1 \text { of GOE } \\
\text { Group IV received a mixture of AGE } \\
\left(62.5 \mathrm{mg} \mathrm{kg}^{-1}\right) \text { and GOE }\left(62.5 \mathrm{mg} \mathrm{kg}^{-1}\right) .\end{array}$ \\
\hline $\begin{array}{l}\text { S. mansoni- } \\
\text { infected }\end{array}$ & $\begin{array}{l}\text { Group V received } 0.1 \mathrm{~mL} \text { of saline } \\
\text { Group VI received } 125 \mathrm{mg} \mathrm{kg}-1 \text { of AGE } \\
\text { Group VII received } 125 \mathrm{mg} \mathrm{kg}-1 \text { of GOE } \\
\text { Group VIII received a mixture of AGE } \\
\left(62.5 \mathrm{mg} \mathrm{kg}^{-1}\right) \text { and GOE }\left(62.5 \mathrm{mg} \mathrm{kg}^{-1}\right) .\end{array}$ \\
\hline
\end{tabular}

\section{Parasitological Study}

Mice were killed by decapitation according the ethical rules and animal experimentation Committee of faculty of science, department of biology, Nalu University at day 49 post infection. After dissecting the animals, the whole liver was put into a $20 \times 20 \mathrm{~cm}$ plastic folder and compressed between two $21 \times 21 \mathrm{~cm}$ glass plates until the parenchyma was smoothly and evenly dispersed into a thin transparent layer then it was examined under a stereomicroscope (EL-Shenawy et al., 2008). The adult worms were sexed and counted referring to the method of reference (Wang et al., 2004). The ending part of small intestine, placed in a Petri dish, was put under stereomicroscope. The male and female worms in the mesenteric veins were removed and counted. Number of Schistosoma eggs per gram of liver was measured (Kloetzel, 1967). The proportion of eggs in various stages of maturity was estimated for oogram study (Pellegring et al., 1962). One hundred eggs per oogram were haphazardly chosen and the qualified by microscopic; they were categorized as dead, viable immature and mature in all infected and treated groups.

\section{Determination of Hematological Parameters}

Decapitation was used to kill mice at day of 49 post infection and blood was collected for hematological and biochemical parameters. Blood samples used for hematological analysis were gathered into polyethylene tubes containing an anticoagulant, ethylene diamine tetraacetic acid (EDTA). The cell counter (ADVIA 60\Cell Dyne counting, ABOTT1800, Ireland) was used to determine erythrocytes (RBCs), total leucocytes counts (WBCs) Hemoglobin (Hb) \%, hematocrit value (PCV) 
and absolute values of erythrocyte indices (EL-Shenawy et al., 2008).

\section{Tissue Malondialdehyde (MDA) and Glutathione} (GSH) Assays

The hepatic reduced glutathione (GSH) level was determined by the method of reference (Ellman, 1959). Briefly, after $0.2 \mathrm{~g}$ liver tissues were homogenized in 4 $\mathrm{mL}$ of $0.02 \mathrm{M}$ EDTA Na2 (using an all glass Ten-Broeck homogenizer in an ice bath). $2.5 \mathrm{~mL}$ tissue homogenates (aliquots) were mixed with $2.0 \mathrm{~mL}$ of distilled water and $0.2 \mathrm{~mL}$ of $50 \%$ TCA. All tubes were shaken intermittently for 10-15 min and centrifuged for $15 \mathrm{~min}$ at approximately $3000 \times \mathrm{g}$. $2.0 \mathrm{~mL}$ of $0.4 \mathrm{M}$ Tris buffer $(\mathrm{pH}$ 8.9) and $0.1 \mathrm{~mL}$ of $0.01 \mathrm{M} \mathrm{5,5}$ '-dithiobis- 2-nitrobenzoic acid (DTNB) were added to $2.0 \mathrm{~mL}$ of tissue supernatant, and the sample was shaken. The absorbance was read within five min of the addition of DTNB at $412 \mathrm{~nm}$ against a reagent blank with no homogenate. GSH levels were calculated using standard curve prepared by known amounts of GSH (Aldrich chemical Co. LTD-Germany). The concentration of GSH was expressed as $\mathrm{mg} / \mathrm{g}$ tissue. Hepatic lipid peroxidation (LPOX) level was measured by a colorimetric reaction with thiobarbituric acid-positive reactant substances (TBARS) and was expressed in terms of the malondialdehyde (MDA) concentration using $1,1,3,3$ - tetraethoxy propane as a standard10. The liver samples were homogenized at the tissue concentration of $50 \mathrm{mg} / \mathrm{mL}$ in $0.1 \mathrm{M}$ of ice-cold phosphate buffer ( $\mathrm{pH}-7.4)$. The homogenates were centrifuged at $10,000 \times \mathrm{g}$ at $4^{\circ} \mathrm{C}$ for five min. $0.5 \mathrm{~mL}$ supernatant was mixed with $0.5 \mathrm{~mL}$ of normal saline and $2 \mathrm{~mL}$ of TBA-TCA mixture. The mixture was boiled at $100^{\circ} \mathrm{C}$ for $10 \mathrm{~min}$, and then cooled at room temperature. This mixture was centrifuged at $4000 \times \mathrm{g}$ for $10 \mathrm{~min}$. The whole supernatant was transferred in spectrophotometer cuvette and read at 535 $\mathrm{nm}$. The levels of TBARS are expressed as micromoles of MDA per $\mathrm{mg}$ of tissue $(\mathrm{mmol} / \mathrm{mg})$.

\section{Determination of Hydrogen Peroxide Radical Scavenging Activity $\left(\mathrm{H}_{2} \mathrm{O}_{2}\right)$}

A method to determine the $\mathrm{H}_{2} \mathrm{O}_{2}$ scavenging ability previously mentioned was used with a little modification (Ruch et al., 1989). Garlic extracts (2 mg/mL) were dissolved in $3 \mathrm{~mL}$ of a $0.1 \mathrm{M}$ phosphate buffer $(\mathrm{pH}=7.4)$ solution and mixed with $600 \mu \mathrm{L}$ of a $43 \mathrm{mM}$ solution of hydrogen peroxide previously prepared in the same buffer. A blank solution was prepared the same way without presence of $\mathrm{H}_{2} \mathrm{O}_{2}$. The absorbance of the solutions was measured for recognizing the concentration of hydrogen peroxide at $230 \mathrm{~nm}$. Gallic acid was used as the reference compound. The hydrogen scavenging activity was calculated using the following equation:

$$
\mathrm{H}_{2} \mathrm{O}_{2} \text { scavenging activity } \%=\frac{\mathrm{A}_{0}-\mathrm{A}_{1}}{\mathrm{~A}_{0}} \times 100
$$

Where $\mathrm{A}_{0}$ was the absorbance of control (blank, without extract) and $\mathrm{A}_{1}$ was the absorbance of the solution in the presence of the extract and gallic acid.

\section{Determination of Ferric Reducing Ability Power} (FRAP)

The FRAP was determined using FRAP assay with some modifications (Benzie et al., 2002). The FRAP solvent included $5 \mathrm{~mL}$ of $10 \mathrm{mMol} / \mathrm{L}$ TPTZ (2, 4, 6tripyridyl- s- triazine) solution in $40 \mathrm{mM} \mathrm{HCl}, 2.5 \mathrm{~mL}$ of $20 \mathrm{mM} \mathrm{FeCl} 3$, and $25 \mathrm{~mL}$ of $0.3 \mathrm{M}$ acetate buffer $(\mathrm{pH}$ 3.6) $(0.3 \mathrm{~mol} / \mathrm{L}, \mathrm{pH}=3.6) .3 \mathrm{~mL}$ FRAP was added to $100 \mu \mathrm{L}$ of mixed sample and the final solution was measured at the absorbance of $593 \mathrm{~nm}$ after incubation at $37^{\circ} \mathrm{C}$ for $10 \mathrm{~min}$. Methanolic solutions of known $\mathrm{Fe}$ (II) concentration, in the range of $0.6-10 \mu \mathrm{mol} / \mathrm{L}\left(\mathrm{FeSO}_{4}\right)$, were used for obtaining the calibration curve. The FRAP value shows the ratio between the slope of the linear scheme for reducing $\mathrm{Fe}^{3+}$-TPTZ reagent by Garlic extract in comparison with the slope of the scheme for $\mathrm{FeSO}_{4}$.

Determination of DPPH Radical Scavenging Activity

DPPH radical scavenging activity in Garlic extracts were determined using the method described by reference (Hatano, 1988). A volume of $40 \mu \mathrm{L}$ of each extract in various concentrations $(3-20 \mathrm{mg} / \mathrm{mL})$ was added to $1 \mathrm{~mL}$ of DPPH (1-1-diphenyl 2-picryl hydrazyl) radical solution dissolved in ethanol with a $0.2 \mathrm{mM}$ final concentration. Two different standards called ascorbic acid and gallic acid $(0.125-20 \mathrm{mg} / \mathrm{mL})$ were reference standards. The different tubes containing the solutions were placed in a dark room for $30 \mathrm{~min}$ to be incubated. The absorbance of mixtures was measured at $520 \mathrm{~nm}$ immediately. The DPPH radical scavenging activity was calculated using the following equation:

$$
\text { DPPH scavenging activity } \%=\frac{A_{0}-A_{1}}{A_{0}} \times 100
$$

$\mathrm{A}_{0}$ was the absorbance of the control (blank, without extract) and $A_{1}$ was the absorbance of the whole materials including extract, ascorbic acid, gallic acid, DPPH. Assay

\section{Determination of Nitric Oxide Radical Inhibition}

Nitric oxide radical inhibition can be measured using Griess Ilosvay reaction reaction (Garrat, 1964). Naphthyl ethylene diamine dihydrochloride $(0.1 \% \mathrm{w} / \mathrm{v})$ was used instead of napthylamine $(5 \%)$. The final combination of mixture $(3 \mathrm{~mL})$ containing phosphate buffer saline $(0.5$ $\mathrm{mL})$, sodium nitroprusside $(10 \mathrm{mM}, 2 \mathrm{~mL})$ and the alcoholic extract of Garlic $(0.5 \mathrm{~mL})$ was incubated at room temperature for $150 \mathrm{~min}$. After incubation, $1 \mathrm{~mL}$ of sulfanilic acid reagent $(0.33 \%$ in $20 \%$ glacial acetic acid) was added to $0.5 \mathrm{~mL}$ of the prepared mixture and allowed to stand for $5 \mathrm{~min}$ for complementation of diazotization. Then, $1 \mathrm{~mL}$ of naphthyl ethylene diamine dihydrochloride was added and allowed to stay at room temperature for 30 min. The final solution had a pinkish color in diffuse light. Ascorbic acid and gallic acid were utilized as the reference compounds. The absorbance of the solutions was measured at $540 \mathrm{~nm}$ in the comparison of blank. The nitric oxide radical scavenging activity was calculated using the following equation.

$$
\text { Nitric oxide scavenging activity } \%=\frac{A_{0}-A_{1}}{A_{0}} \times 100
$$


Where $\mathrm{A}_{0}$ was the absorbance of the control (blank, without extract) and $A_{1}$ was the absorbance of the whole materials including extract, ascorbic acid and gallic acid.

\section{Statistical Analysis}

All the investigations were carried out in triplicate. Experimental information was revealed as mean \pm standard deviation (SD). SPSS software, Version 19.0, was used to analyze the data. One way analysis of variance was provided by ANOVA procedures. Values of $\mathrm{P}<0.05$ were organized as significant utilizing Duncan's multiple range tests to show the differences between means.

\section{Results and Discussion}

\section{In vivo Studies}

Plants have been used as nonconventional Anthelmintics with considerable attention in recent times due to world-wide development of resistance to chemical anthelmintics in worm populations (Kamel and ElShinnawy, 2015; El-Kott et al., 2011). In the last years, plant extracts have been utilized in treatment of $S$. mansoni infection (Molgaard et al., 2001; Kamel and ElShinnawy 2015). This work was aimed to assess the effect and potency of GOE and AGE secretly and as a mixture in treating $S$. mansoni and introducing more potent extract in treatment of S. mansoni. As it is represented in the current paper, garlic has the antiparasitic mode of action. It has been reported that this mechanism of action is made by enhancing the immunity of the host to attack the parasite (EL-Shenawy et al., 2008). It is also thought that the antioxidative properties of both AGE and GOE have strong effects in Schistosoma infected mice (EL-Shenawy et al., 2008; Kamel and El-Shinnawy, 2015; El-Kott et al., 2011). The development of eggs are continued in the tissue until maturation, then until the time of death, the mature ova are remained alive in the tissue. Accordingly, it has been reported that, garlic effects on the reproductive organs of the worms (El-Kott et al., 2011). As shown in Figure 2, groups VI treated with AGE (17.33 \pm 2.69$)$ contained more mature eggs than the groups treated with GOE $(14.33 \pm 1.69)$ and both extracts (AGE + GOE) $(14.66 \pm 1.24)$ while the number of mature eggs were decreased in all tested groups comparing to group $\mathrm{V}$ $(40.33 \pm 0.41)$. GOE could decrease the number of mature eggs much more than the other two groups treated by $\mathrm{AGE}$ or AGE + GOE. The number of immature eggs was higher in VI (73.66 \pm 1.69$)$ and VII (72.33 \pm 1.61$)$ compared to VIII $(67.33 \pm 2.44)$ while all the test samples were effective in increasing the number of immature eggs in comparison to $\mathrm{V}(54.31 \pm 1.42)$, as a result, it can be obvious that AGE could increase the number of immature eggs higher than the other two groups with a slight difference. On the other hand, VIII $(17.31 \pm 1.76)$ could be able to increase the number of dead eggs much higher than VI $(9.01 \pm 0.34)$ and VII (13.21 \pm 0.89$)$ samples while all samples showed remarkable increase in the number of dead eggs in comparison to $\mathrm{V}(5.35 \pm 2.16)$ surprisingly. As a result, it can be reported that the VIII group was able to cause high number of dead eggs compared to the other tested extracts, which are shown in
Figure 2. It was exhibited that aqueous garlic extract disrupted the development and maturity of Schistosoma eggs as there was an increase in number of dead eggs (EL-Shenawy et al., 2008). It can be obtained that, there is a correlation between the number of worms with the reduction of the ova due to the possible linear relationship between the egg output and the worm burden (Riad et al., 2007). However, there should be numerous possibilities responsible for the reduction of eggs. The mentioned factors may be responsible for diminishing fecundity of the worm pairs and cause an increase in the rate of egg excretion according to the worm pairs (Mantawy et al., 2011). As displayed in Figure 1, the number of total worms including male and female worms were decreased in infected mice treated with AGE+ GOE $(1015 \pm 1.41)$ compared to infected untreated mice $(1502 \pm 2.13)$ notably.

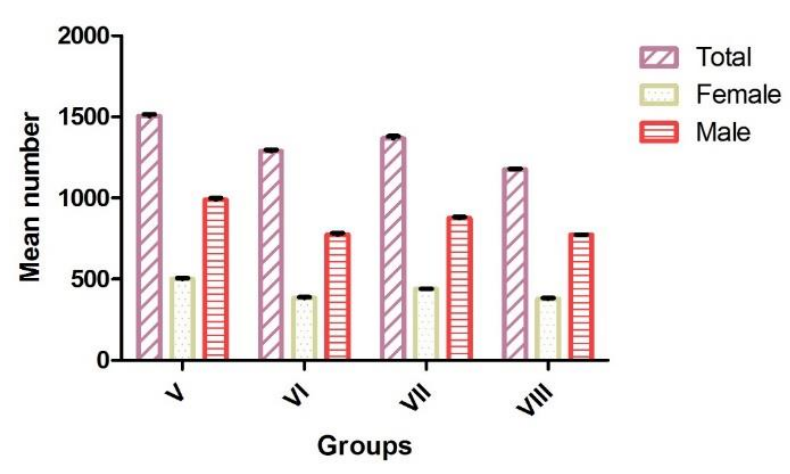

Figure 1 Mean number of adult worms recovered from $S$. mansoni-infected mice after administration of $125 \mathrm{mg} \mathrm{kg}^{-}$

${ }^{1}$ of GOE, $125 \mathrm{mg} \mathrm{kg}^{-1}$ of AGE separately or in combination (62.5 from each).

V-VIII: S. mansoni infected mice; VI: treated with AGE, VII: treated with GOE, VIII: treated with mixture of GOE and AGE.

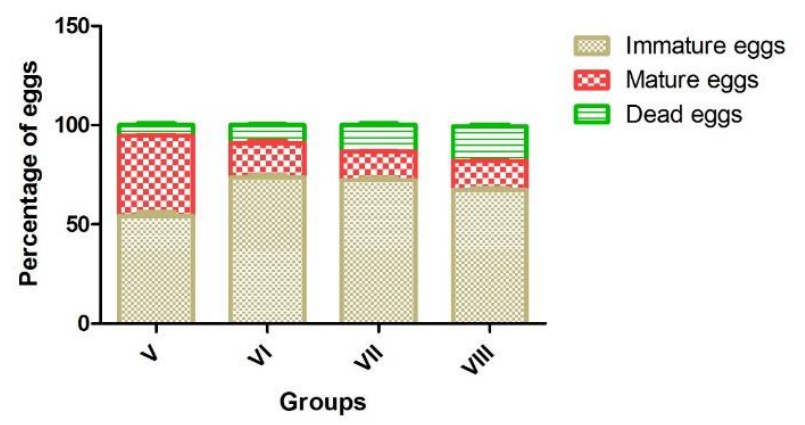

Figure 2 Percentage of eggs (immature, mature and dead) after administration of $125 \mathrm{mg} \mathrm{kg}^{-1}$ of GOE, $125 \mathrm{mg} \mathrm{kg-1}$ of AGE separately or in combination.

V-VIII: S. mansoni infected mice, VI: treated with AGE, VII: treated with GOE, VIII: treated with mixture of GOE and AGE.

It was also reported that, the more immunoglobulins elevated there were, the more reactive oxygen was decreased in treatment of schistosomiasis, therefore, this mechanism can be happened through antioxidants defenses from infected hepatic cells increasing constant oxidative stress and oxidation of lipids, protein and other macromolecules such as DNA (Mantawy et al., 2011). Anemia was observed due to a strong decrease in the level of $\mathrm{Hb}$ percentage in infected untreated mice $(7.6 \pm 0.3$, $\mathrm{P} \leq 0.05)$ compared to non-infected untreated mice $(11.2 \pm$ 
$0.2, \mathrm{P} \geq 0.05)$ therefore it decreased the number of RBCs, Group VI treated with $125 \mathrm{mg} \mathrm{kg1}$ of AGE $(8.5 \pm 0.4$, $\mathrm{P}<0.001)$ showed the highest amount of WBCs compared to non-infected group, besides, the number of PVC was also decreased in untreated infected mice $(33.54 \pm 0.1$, $\mathrm{P} \leq 0.01)$ in comparison with non-infected untreated mice $(41.36 \pm 0.6, \mathrm{P} \geq 0.05)$. As it is shown in Table 2, the number of Thrombocytes, components of blood to stop bleeding, was increased in infected untreated mice (685 \pm $8.5, \mathrm{P} \leq 0.05)$ in comparison to the non-infected untreated mice $(344 \pm 2.9, \mathrm{P} \geq 0.05)$. Parallel to the present study, it was represented that anemia could be observed in the case of reduction in the level of three different parameters such as RBC count; PCV and Hb content (EL-Shenawy et al., 2008). According to the results, interaction of AGE + GOE in both infected $(17.5 \pm 0.5, \mathrm{P} \leq 0.01)$ and noninfected $(18.4 \pm 0.4, \mathrm{P} \leq 0.01)$ groups enhanced the $\mathrm{Hb}$ percentage more than the action of AGE (noninfected:14.1 $\pm 0.1, \mathrm{P} \geq 0.05$; infected: $9.1 \pm 0.5, \mathrm{P} \leq 0.01)$ and GOE (non-infected: $12.8 \pm 0.2, \mathrm{P} \geq 0.05$; infected: 9.3 $\pm 0.2, \quad \mathrm{P} \leq 0.01$ ), apart from this, all infected groups including untreated and treated groups showed a notable decrease in number of RBCs secretion, which are all shown in Table 2. Accordingly, it was represented that the mentioned decreases were caused by two ways including extrusion of egg through intestinal wall ending to the bleeding or consumption by adult schistosomes (Sturrock et al., 1996). A key antioxidant namely GSH is an essential constituent of intracellular protective mechanisms against oxidative stress (Ross, 1988). In experimental liver fibrosis, the more antioxidants are decreased, the freer radicals are secreted; thereby, cellular damage is increased (Yang et al., 2004). Our results showed that the administrations of both garlic extracts separately or in combination prevent the hepatic GSH depletion, so that, garlic extracts are stressed to contain strong potent of antioxidant capacity in protecting the hepatic tissue against oxidative stress. The results also displayed that there was a significant increase in the hepatic MDA levels of infected mice probably along with scavenging the very reactive hydroxyl and peroxyl radicals. The GOE extract could decrease the MDA levels of both non-infected $(0.51 \pm 0.45, \mathrm{P} \geq 0.05)$ and infected $(0.32 \pm 0.23, \mathrm{P} \leq 0.01)$ mice stronger than the other extracts while the AGE extract could decrease the level of GSH in both non-infected $(0.96 \pm 0.06, \mathrm{P} \leq 0.05)$ and infected mice $(0.31 \pm 0.31, \mathrm{P} \leq 0.05)$ much stronger than the other utilized extracts which are shown in Table 3 . It can be emphasized that, AGE had the highest potential in GSH depletion and is introduced as a potent antioxidant in comparison to GOE and AGE+ GOE. In accordance to the present study, it was also reported that chronic garlic intake decreased lipid peroxidation and increased endogenous antioxidants, such as catalase and GSH significantly (Banerjee and Maulik, 2002).

\section{Determination of Different Radical Scavenging Activities}

One of the most derivations of Hydrogen peroxide called hydroxyl radical initiating lipid peroxidation can cause DNA damage (Nakayama et al., 1993). In the body, protein and DNA should be protected via removing hydrogen peroxide because of its high potential in hydroxyl radicals' secretion. Hydroxyl radicals are highly reactive and short-lived radicals with high potential of disruption (Zhao et al., 2008; Hayyan et al., 2016). The hydrogen peroxide scavenging activities of extracts which are represented in Table confirmed that, AGE, GOE and $\mathrm{AGE}+\mathrm{GOE}$ extracts represented high $(99.76 \pm 2.34 \%)$, moderate $(70.85 \pm 2.87 \%)$ and low $(35.45 \pm 1.22 \%)$ scavenging capacity against $\mathrm{H}_{2} \mathrm{O}_{2}$, respectively. AGE $(99.76 \pm 2.34)$ had the strongest potential of $\mathrm{H}_{2} \mathrm{O}_{2}$ radical Scavenging activity in comparsion to Galic acid (15.41 \pm 1.24), therefore it can be suggested that AGE contains effective necessary compounds for hydrogen peroxide elimination.

\section{Determination of Ferric Reducing Ability Power (FRAP)}

The FRAP method called Ferric ion reducing antioxidant power is an antioxidant capacity assay that uses Trolox as a standard (Benzie et al., 1996). In this study, it was used to evaluate the reducing potential of the tested extracts. In the presence of antioxidants, it reduces a ferric 2,4,6-tripyridyl-s-triazine complex (Fe3+-TPTZ) to its ferrous colored form (Fe2+-TPTZ). The results of the present study displayed that, in the presence of 125 mg kg-1 of samples, FRAP activity of GOE (397.75 \pm 3.47) was the highest compared to AGE $(279.51 \pm 3.40)$ and AGE + GOE (314.63 \pm 5.65$)$. As it is displayed in Table 4, the FRAP activity of all tested compounds were less than standards.

Table 2 Some blood parameters after administration of aqueous garlic extract $\left(125 \mathrm{mg} \mathrm{kg}^{-1}\right)$ and GOE $\left(125 \mathrm{mg} \mathrm{kg}^{-1}\right)$ or the mixture of both mentioned extracts.

\begin{tabular}{c|cccccc}
\hline Groups of mice & & WBCs & RBCs & Hb\% & PCV & Thrombocytes \\
\hline & I & $2.24 \pm 0.2$ & $9.76 \pm 0.4$ & $11.25 \pm 0.2$ & $41.36 \pm 0.6$ & $344 \pm 2.9$ \\
Non-infected control & II & $4.98 \pm 0.3^{\mathrm{a}}$ & $9.45 \pm 0.2$ & $14.11 \pm 0.1$ & $49.93 \pm 0.4^{\mathrm{a}}$ & $695 \pm 4.0^{\mathrm{a}, \mathrm{b}}$ \\
& III & $2.12 \pm 0.4$ & $10.90 \pm 0.4$ & $12.82 \pm 0.2$ & $46.71 \pm 0.5^{\mathrm{a}}$ & $332 \pm 7.9$ \\
& IV & $4.23 \pm 0.3^{\mathrm{a}}$ & $10.65 \pm 0.3$ & $18.41 \pm 0.4^{\mathrm{d}}$ & $52.51 \pm 0.3^{\mathrm{a}}$ & $335 \pm 8.4$ \\
\hline & V & $7.13 \pm 0.1$ & $5.17 \pm 0.4$ & $7.63 \pm 0.3^{\mathrm{c}}$ & $28.32 \pm 0.1^{\mathrm{c}}$ & $685 \pm 8.5^{\mathrm{ab}}$ \\
& VI & $8.51 \pm 0.4^{\mathrm{c}}$ & $4.93 \pm 0.1$ & $9.15 \pm 0.5^{\mathrm{d}}$ & $33.54 \pm 0.1^{\mathrm{c}, \mathrm{d}}$ & $882 \pm 7.6^{\mathrm{a}}$ \\
& VII & $5.43 \pm 0.3$ & $5.42 \pm 0.2$ & $9.36 \pm 0.2^{\mathrm{d}}$ & $33.83 \pm 0.4^{\mathrm{c}, \mathrm{d}}$ & $382 \pm 11.0^{\mathrm{c}, \mathrm{d}}$ \\
& VIII & $4.65 \pm 0.1$ & $5.21 \pm 0.1$ & $17.52 \pm 0.5^{\mathrm{d}}$ & $30.83 \pm 0.6^{\mathrm{b}, \mathrm{c}, \mathrm{d}}$ & $623 \pm 10.3^{\mathrm{ab}}$ \\
\hline
\end{tabular}

RBCs; Erythrocytes count, WBCs; total leucocytes count, Hb\%; Hemoglobin, PCV; hematocrit value. I-IV non-infected control groups of mice treated with $0.2 \mathrm{mLsaline}, 125 \mathrm{mg} \mathrm{kg}^{-1}$ of AGE, GOE $125 \mathrm{mg} \mathrm{kg}^{-1}$ and the mixture of both mentioned extracts $\left(62.5 \mathrm{mg} \mathrm{kg}^{-1}\right.$ from each). V-VIII $S$. mansoni infected mice treated as mentioned above. The data are presented as mean $\pm \mathrm{S} . \mathrm{D}, \mathrm{n}=6-8$. The minimum and maximum values are shown in

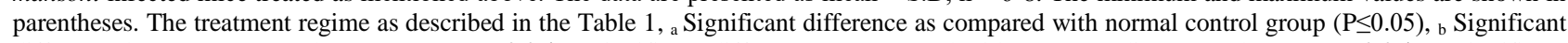
difference between GOE and AGE groups $(\mathrm{P} \leq 0.05)$, c Significant difference as compared with corresponding control group ( $\mathrm{P} \leq 0.05)$, d Significant difference as compared with infected group $(\mathrm{P} \leq 0.01)$. 
Table 3 GSH and MDA after administration of aqueous garlic extract $\left(125 \mathrm{mg} \mathrm{kg}^{-1}\right)$ and GOE $\left(125 \mathrm{mg} \mathrm{kg}^{-1}\right)$ or the mixture of both mentioned extracts $\left(62.5 \mathrm{mg} \mathrm{kg}^{-1}\right.$ from each).

\begin{tabular}{c|lcc}
\hline Groups of mice & & Malondialdehyde (MDA) level & glutathione (GSH) level \\
\hline & I & $0.56 \pm 0.03$ & $1.91 \pm 0.04$ \\
Non-infected control & II & $0.76 \pm 0.43$ & $0.96 \pm 0.06^{\mathrm{ab}}$ \\
& III & $0.51 \pm 0.45$ & $1.02 \pm 0.54^{\mathrm{ab}}$ \\
& IV & $0.66 \pm 0.65$ & $2.65 \pm 0.43$ \\
\hline & V & $2.33 \pm 0.12^{\mathrm{c}}$ & $0.33 \pm 0.12^{\mathrm{c}}$ \\
S. mansoni- infected & VI & $0.52 \pm 0.43^{\mathrm{d}}$ & $0.31 \pm 0.31^{\mathrm{d}}$ \\
& VII & $0.32 \pm 0.23^{\mathrm{d}}$ & $0.66 \pm 0.08^{\mathrm{d}}$ \\
& VIII & $0.54 \pm 0.36^{\mathrm{d}}$ & $0.68 \pm 0.41^{\mathrm{d}}$ \\
\hline
\end{tabular}

GSH and MDA after administration, the data are presented as mean \pm S.E, $\mathrm{n}=6-8$. I-IV non-infected control groups of mice treated with $0.2 \mathrm{~mL}$ saline, $125 \mathrm{mg} \mathrm{kg}-1$ of GOE, $125 \mathrm{mg} \mathrm{kg}-1$ of AGE, mixture of GOE and AGE (62.5 mg kg-1 from each), respectively. V-VIII S. mansoni infected mice treated as mentioned above, a Significant difference as compared with normal control group $(\mathrm{P} \leq 0.05)$, $\mathrm{b}$ Significant difference between GOE and AGE groups ( $\mathrm{P} \leq 0.05)$, Significant difference as compared with corresponding control group ( $\mathrm{P} \leq 0.05)$, d Significant difference as compared with infected group ( $\mathrm{P} \leq 0.01)$, Table 4: Free radical scavenging activity of AGE, GOE and GOE + AGE (62.5 mg kg-1 from each).

Table $4 \mathrm{H}_{2} \mathrm{O}_{2}$, FRAP, nitric oxide and DPPH radical scavenging activities values of AGE, GOE and GOE + AGE

\begin{tabular}{l|cccc}
\hline \multicolumn{1}{c}{ Extract } & $\begin{array}{c}\mathrm{H}_{2} \mathrm{O}_{2} \text { radical Scavenging } \\
\text { activity }(\%)\end{array}$ & $\begin{array}{c}\text { FRAP value } \\
(\mu \mathrm{mol} / 100 \mathrm{~g})\end{array}$ & $\begin{array}{c}\text { DPPH scavenging } \\
\text { activity\% }\end{array}$ & $\begin{array}{c}\text { Nitric oxide scavenging } \\
\text { activity } \%\end{array}$ \\
\hline AGE & $99.76 \pm 2.34 \mathrm{~d}$ & $279.51 \pm 3.40 \mathrm{a}$ & $97.95 \pm 1.03 \mathrm{a}$ & $74.35 \pm 3.45 \mathrm{a}$ \\
$\mathrm{GOE}$ & $70.85 \pm 2.87 \mathrm{c}$ & $397.75 \pm 3.47 \mathrm{a}$ & $94.54 \pm 0.83 \mathrm{c}$ & $81.22 \pm 4.52 \mathrm{c}$ \\
$\mathrm{AGE}+\mathrm{GOE}$ & $35.45 \pm 1.22 \mathrm{~b}$ & $314.63 \pm 5.65 \mathrm{a}$ & $96.67 \pm 2.47 \mathrm{~b}$ & $74.35 \pm 3.61 \mathrm{a}$ \\
Gallic acid & $15.41 \pm 1.24 \mathrm{a}$ & $812.56 \pm 5.91 \mathrm{c}$ & $94.66 \pm 0.70 \mathrm{c}$ & $63.25 \pm 3.44 \mathrm{~b}$ \\
Ascorbic acid & - & $467.56 \pm 3.14 \mathrm{~b}$ & $93.20 \pm 0.56 \mathrm{c}$ & $69.06 \pm 2.77 \mathrm{~b}$ \\
\hline
\end{tabular}

Each value is presented as the mean $\pm \operatorname{SD}(n=3)$

Determination of DPPH Radical Scavenging Activity

An organic chemical compound, 2,2-diphenyl-1picrylhydrazyl, is a dark-colored crystalline powder composed of stable free-radical molecules. It is a stable purple free radical and accepts an electron or hydrogen radical to become a stable yellow compound (diphenylpicrylhydrazine) at room temperature. The reduction of DPPH induced by antioxidants are measured by the decrease in its absorbance at $520 \mathrm{~nm}$ (Brand-Williams et al., 1995; Sharma et al., 2009). As it is shown in Table 4, all extracts could overtake the standards. Accordingly, AGE $(97.95 \pm 1.03 \%)$ had the strongest potential of DPPH scavenging activity compared to AGE + GOE $(96.67 \pm 2.47 \%)$ and GOE $(94.54 \pm 0.83 \%)$. Therefore, it can be expressed that AGE had the highest DPPH free radical scavenging activity and reducing power.

Determination of Nitric oxide radical inhibition assay

Nitric oxide, which is a free radical with chemical formula of $\mathrm{NO}$ is one of several oxides of nitrogen. Interactions of NO with reactive oxygen species (ROS) such as $\mathrm{H}_{2} \mathrm{O}_{2}$ and $\mathrm{O} 2$ - can be either protective or cytotoxic (Beligni et al., 2009; Lund et al., 2011). Although oxidative injury can be limited in physiological level of No, high concentration of NO cause the production of $\mathrm{N}_{2} \mathrm{O}_{3}$ and $\mathrm{ONOO}$ - which are strong reactive nitrogen oxide species and can be the reason for causing toxic reactions including lipid peroxidation, DNA modification and $\mathrm{SH}$ - oxidation Griess Ilosvay reaction can be used for measuring nitric oxide radical inhibition (Moncada et al., 1991). As it is displayed in table 4, all tested samples including GOE (81.22 $\pm 4.52 \%)$ and AGE $+\operatorname{GOE}(74.35 \pm 3.61)$ and AGE (74.35 \pm 3.45$)$ could overtake the tested standards including gallic acid $(63.25$ $\pm 3.44)$ and ascorbic acid $(69.06 \pm 2.77)$, therefore can be reported that GOE has the highest potential in terms of Nitric oxide scavenging activity.

\section{Conclusion}

In conclusion, it could be reported that all tested samples including AGE, GOE and AGE + GOE could decrease the total number of worms including male and female while AGE + GOE could affect the total number of eggs higher than the separately used extracts (AGE or GOE) with a slight difference. In terms of mature, immature and dead eggs, it can also be suggested that $\mathrm{AGE}+\mathrm{GOE}$ extract was able to increase the number of dead eggs more than the other extracts while both AGE and GOE extracts used separately could increase the number of immature eggs, so it is being suggested that all tested samples had potential in prohibition of the unwanted parasites of schistosomiasis disease whereas AGE + GOE could be more effective in comparison to the other samples. The level of GSH was depleted with all tested samples while AGE showed higher level of depletion, which meant that AGE was a potent antioxidant. It can be obtained that almost all tested extracts were highly effective $\mathrm{H}_{2} \mathrm{O}_{2}$, nitric oxide, DPPH radical scavengers while any of the tested extracts could not overtake the standards in terms of FRAP value.

\section{Acknowledgment}

Authors are thankful to faculty of animal biology, department of science and technology, Urmia University, Iran for their help. 


\section{References}

Anthony JP, Fyfe L, Smith H. 2005. Plant active components - a resource for antiparasitic agents. Trends. Parasitology 21: 462-468.

Amagase H, Milner JA. 1993. Impact of various sources of garlic and their constituents on 7: 12-dimethylbenz [a] anthracene binding to mammary cell DNA. Carcinogenesis 14: 1627-1631.

Abd El-Galil MAA, Aboelhadid SM. 2012. Trials for the control of trichodinoisis and gyrodactylosis in hatchery reared Oreochromis niloticus fries by using garlic. Veterinary Parasitology. 185: 57-63.

Banerjee Sk, Maulik SK. 2002. Effect of garlic on cardiovascular disorders: a review. Nutrition Journal 1: 114.

Bayan L, Koulivand PH, Gorji A. 2014. Garlic: a review of potential therapeutic effects. Avicenna Journal of Phytomedicine journal 4: 1-14.

Beligni MV, Fath A, Bethke PC, Lamattina L, Jones RL. 2002. Nitric oxide acts as an antioxidant and delays programmed cell death in barley aleurone layers. Plant physiology 129 : 1642-1650.

Benkeblia N. 2005. Free-Radical Scavenging Capacity and Antioxidant Properties of Some Selected Onions (Allium cepa L.) and Garlic (Allium sativum L.) Extracts. Brazilian Archives of Biology and Technology 48: 753-759.

Benzie IF, Strain JJ. 1996. The Ferric Reducing Ability of Plasma (FRAP) as a Measure of "Antioxidant Power": The FRAP Assay. Analytical Biochemistry 239: 70-76.

Benzie FFI, TomLinson B, Szeto YT. 2002. Total antioxidant and ascorbic acid content of fresh fruits and vegetables: implications for dietary planning and food preservation. British journal of nutrition Nutrition Society 87: 55-59.

Brand-Williams W, Cuvelier ME, Berset C. 1995. Use of a Free Radical Method to Evaluate Antioxidant Activity. Food Science and Technology 28: 25-30.

El-Kott AF, Mohammed RT, Ismail NR. 2011. Efficacy of garlic and mirazid in treatment of the liver granuloma in mice infected with Schistosoma mansoni. Research Journal of Parasitology 6: 151-159.

Ellman GL. 1959. Tissue sulfhydryl groups. Arch. Biochemistry and Biophysics 82: 70-77.

EL-Shenawy NS, Soliman MFM, Reyad SI. 2008. The effect of antioxidant properties of aqueous garlic extract and Nigella sativa as antischistosomiasis agents in mice. Revista do Instituto de Medicina Tropical de São Paulo 50: 29-36.

FAO. Production and trade statistics.Rome, Italy: FAO. 2013.

Garrat DC. 1964. The quantitative analysis of drugs. Chapman and Limited. Japan. 456-458.

Hatano T., Kagaw H., Yasuhar T., Okuda T. 1988. Two new flavonoids and other constituentsinlicorice root: their relative astringency and radical scavenging effects. Chemical and Pharmaceutical Bulletin 36: 1090-2097.

Hayyan M, Hashim MA, AlNashef IM. 2016. Superoxide Ion: Generation and Chemical mplications. Chemical Reviews 116: 3029-3085.

Jegede T. 2012. Effect of garlic (Allium sativum) on growth, nutrient utilization, resistance and survival of Tilapia zillii (Gervais 1852) fingerlings. Journal of Agricultural Science 4: 269-274.

Kahkonen M.P., Hopia A.I., Vuorela H.J., Rauha J.P., Pihlaja K., Kujala T.S., Heinonen M. 1999. Antioxidant activity of plant extracts containing phenolic compounds. Journal of Agricultural and Food Chemistry 47: 3954-3962.

Kamel RO, El-Shinnawy NA. 2015. Immunomodulatory effect of garlic oil extract on Schistosoma mansoni infected mice. Asian Pacific Journal of Tropical Medicine 8: 999-1005.
Kasuga S, Uda N, Kyo E, Ushijima M. Morihara, N., Itakura, Y. 2001. Pharmacologic activities of aged garlic extract in comparison with other garlic preparations. Journal of Nutrition 131: 1080-1084.

Kloetzel K. 1967. Egg and pigment production in Schistosoma mansoni infections of the white mouse. American Journal of Tropical Medicine 16: 293-299.

Lanzotti V, Scala F, Bonanomi G. 2014. Compounds from Allium species with cytotoxic and antimicrobial activity. Phytochemistry Reviews 13: 769-791.

Lawrence R, Lawrence K. 2011 Antioxidant activity of garlic essential oil (Allium Sativum) grown in north Indian plains. Asian Pacific Journal of Tropical Biomedicine 1: 51-54.

Lund A, Shigetaka S, Masaru S. 2011. Principles and Applications of ESR Spectroscopy. ISBN. 978: 5344-5353.

Morihara N, Hayama M, Fujii H. 2011. Aged garlic extract scavenges superoxide radicals. Plant Foods for Human Nutrition 66: 17-21.

Mantawy MM, Ali HF, Rizk MZ. 2011. Therapeutic effects of Allium sativum and Allium cepa in Schistosoma mansoni experimental infection. Revista do Instituto de Medicina Tropical de São Paulo 53: 155-163.

Martins ML, Moraes FR, Miyazaki DM, Brum CD, Onaka EM, Fenerick JJ, Bozzo FR. 2002. Alternative treatment for Anacanthorus penilabiatus (Monogenea: Dactylogyridae) infection in cultivated pacu, Plaractus mesopotamicus (Osteichthyes: Characidae) in Brazil and its haematological effects. Parasite 9: 175-180.

Militz TA, Southgate PC, Carton AG, Hutson KS. 2013. Dietary supplementation of garlic (Allium sativum) to prevent monogenean infection in aquaculture. Aquaculture 408: 9599.

Molgaard P, Nielsen SB, Rasmussen DE, Drummond RB, Makaza N, Andreassen J. 2001. Antheminthic screening of Zimbabwean plants traditionally used against schistosomiasis. Journal of Ethnopharmacology 74: 257264.

Moncada S, Palmer RM, Higgs EA. 1991. Nitric oxide: physiology, pathophysiology, and pharmacology. Pharmacological Reviews 43: 109-142.

Nakayama T, Yamaden M, Osawa T, Kawakishi S. 1993. Suppression of active oxygen-induced cytotoxicity by flavonoids. Biochemical Pharmacology 45: 265-267.

Pellegring J, Olievira CA, Faria J, Cunha AS. 1962. New approach to the screening of drugs in experimental schistosomiasis mansoni in mice. American Journal of Tropical Medicine and Hygiene 11: 201-215.

Rahman K, Lowe GM. 2006. Garlic and cardiovascular disease: a critical review. Journal of Nutrition 136: 736-740.

Rahman MM, Fazlic V, Saad NW. 2012. Antioxidant properties of raw garlic (Allium sativum) extract. International Food Research Journal 19: 589-591.

Riad NH, Fares NH, Mostafa OM, Mahmoud YI. 2007. The effect of garlic on some parasitological parameters and on hepatic tissue reactions in experimental schistosomiasis mansoni. Journal of applied sciences research 3: 949-960.

Rodgers CJ, Furones MD. 2009. Antimicrobial agents in aquaculture: practice, needs and issues. Options Méditerranéennes 86: 41-59.

Ross D. 1988. Glutathione, free radicals and chemotherapeutic agents. Mechanisms of freeradical induced toxicity and glutathione-dependent protection. Pharmacology \& Therapeutics 37: 231-249.

Ruch RJ, Cheng ST, Klauring JE. 1989. Prevention of cytotoxicity and inhibition of intercellular communication by antioxidant catechins isolated from Chinese green tea. Carcinogenesis 10: 1003-100.

Sattler M, Griffin JD. 2003. Molecular mechanisms of transformation by the BCR-ABL oncogene. Seminars in Hematology 40: 4-10. 
Schelkle B, Snellgrove D, Cable J. 2013. In vitro and in vivo efficacy of garlic compounds against Gyrodactylus turnbulli infecting the guppy (Poecilia reticulata). Veterinary Parasitology 198: 96-101.

Sener G, Satyroglu H, Ozer-Sehirli A, Kacmaz A. 2003. Protective effect of aqueous garlic extract against oxidative organ damage in a rat model of thermal injury. Life Sciences 73: 81-91.

Sharma OP, Bhat TK. 2009. DPPH antioxidant assay revisited. Food chemistry 113: 1202-1205.

Sturrock RF, Kariuki HC, Thiongo FW, Thiongo FW, Gachare JW, Omondi BGO, Ouma JH, Mbugua G, Butterworth AE. 1996. Schistosomiasis mansoni in Kenya: relationship between infection and anemia in schoolchildren at the community level. Transactions of the Royal Society of Tropical Medicine and Hygiene 90: 48-54.

Tanaka S, Haruma K, Yoshihara M, Kajiyama G, Kira K, Amagase H, Amagase H, Chayama K. 2006. Aged garlic extract has potential suppressive effect on colorectal adenomas in humans. Journal of Nutrition 136: 821-826.
Thomas MJ. 1995. The role of free radicals and antioxidants: how do we know that they are working. Critical Reviews in Food Science and Nutrition 35: 21-39.

Wang Y, Holmes E, Nicholson JK, Cloarec O, Chollet J. 2004. Metabonomic investigations in mice infected with Schistosoma mansoni: an approach for biomarker identification. Proceedings of the National Academy of Sciences 24: 12676-12681.

Yang S, Tan TM, Wee A, Leow CK. 2004. Mitochondrial respiratory function and antioxidant capacity in normal and cirrhotic livers following partial hepatectomy. Cellular and Molecular Life Sciences 61: 220-229.

Zhao GR, Zhang HM, Ye TX, Xiang ZJ, Yuan YJ, Guo ZX, Zhao LB. 2008. Characterization of the radical scavenging and antioxidant activities of danshensu and salvianolic acid B. Food and Chemical Toxicology 46: 73-81. 